\title{
The Triadic Structure of Wa People's Environmental Customary Law Origin
}

\author{
Jingyi Wang ${ }^{1}$, Xiaoyan $\mathrm{Li}^{1}$ \\ ${ }^{1}$ Yunnan Normal University, Kunming, Yunnan Province, China
}

Keywords:Wa people; environmental customary law; Origin; Structure.

\begin{abstract}
Environmental customary law refers to ideas and opinions on the relationship between human and the natural environment in the traditional culture of minority nationalities. It reflects the original legal culture of ethnic minorities. Wa people are indigenous minorities in Yunnan. Their traditional culture contains a large number of environmental customary law elements on the harmonious relationship between human and the natural environment. This article analyzes the traditional culture of Wa people, and finds that their environmental customary law comes from three origins: religion and taboo, symbolic culture and institution.
\end{abstract}

\section{Introduction}

Wa is one of the main ethnic groups in China, and one of the oldest ethnic groups in Yunnan Province. Wa language belongs to the Palaungic branch of the Austroasiatic language family, and has no script. According to the results of the sixth national census, the population of Wa is about 420 thousand people, distributed mainly in Yunnan, Ximeng, Cangyuan and other places. According to relevant data [1], until 1950s, Wa society was still in the relatively backward stage of slash-and-burn cultivation. Their production and way of life develop slowly. Meanwhile, the means of transportation and communication are relatively inconvenient. Therefore, Wa people do not have close social contact with the outside world, and are able to keep their original ecological culture, which is characterized by the harmony between man and nature. This kind of cultural trait is expressed by different cultural forms, and forms a unique Wa culture circle. In the culture circle, the interaction rules and orders with the natural environment is mainly manifested in environmental customary law, which is implied in national religion and legal regulations. The content of customary law relates to every aspects of life. It includes concepts of respecting life, reverence for nature and harmonious coexistence, which shows the original wisdom of Wa people.

\section{The Traditional Culture Origin of Environmental Customary Law}

The traditional culture of Wa nationality is precious non-material wealth that has the most local and national characteristics, and conveys the original wisdom of the harmony between people and the natural environment.

First is the traditional Si Gang Li of Wa nationality. Si Gang Li is not only a legend pass on from generation to generation, but also one of the indispensable songs which need to be sung in all kinds of ceremonies. According to records, Wa people sing the song for hours in all formal religious ceremonies and major festivals. In Wa language, Si Gang Li refers to stone or gourd. The legend goes as follows. 'God Lu An and God Li Ji separated heaven from the earth. Then, after the creation of animals, the sun and the moon, Gods made man. Finally, they put man in Si Gang. It was difficult to live in it, and people could hear many animals chipping it. In the end, sparrows broke Si Gang by their sharp beaks... Man was born from the hole... Remember the kindness of sparrow; sing the warmth of the sun. The ode of Si Gang Li passes on from generation to generation.'[2] In the meantime, Si Gang Li records that, after Wa people went out of Si Gang, they experienced hardships in migration. The legend also mentions life, production, consumption and distribution. In a word, Wa people in Si Gang $\mathrm{Li}$ advocate unity and the harmony with nature. The song expresses Wa people's view and understanding of the world and natural environment. From these myths and legends, it can be seen that Wa people believe that human beings are a part of nature, and that the birth of human beings is 
the result of animals' and plants' help. Therefore, animals are friends of human beings, and human need to get along well with them. Si Gang Li also implies that, people and other creatures are created at the same time, and human has equal status with all other things. No one is superior to others. Si Gang Li tells about the origin of human beings, and more importantly, it 'has become the most sacred complex in the heart of Wa people. Like the Bible, Si Gang Li is regarded as the cultural, politics, ethics, philosophy, religious and legal textbook for Wa people, and has become an essential classic in their primitive consciousness.'[3] Therefore, Si Gang Li not only embodies their traditional wisdom, but also serves as the cultural roots of original laws. It inherits Wa people's views on rules and orders, and expresses their world outlook and viewpoint of value in basic legal culture. This kind of value is the value of harmony between man and nature, which has profound influence on the environmental customary law of Wa nationality. Si Gang $\mathrm{Li}$ is one of the most important sources of the environmental customary law of Wa people.

Second is the wooden drum culture. Wooden drums have cultural significance for Wa people. In their traditional culture, wooden drums are of great importance. They are the symbol of their spiritual life, the vivid and direct embodiment of Wa culture, and the derivative of their primitive religious belief. Developed in the long time historical process, wooden drums are instruments which can show the spirit of Wa culture. Drums of Wa nationality are made of tree trunks. Beaten by drum sticks, they can produce unique sound. According to historical records, before 1960s, wooden drums are mainly used for sending messages, expressing beliefs and calling villagers together. Drums have relatively simple appearance, but they are tools to communicate with deities and send signals of the war. Wooden drums can be used to exorcise ghosts in ritual activities, and call villagers together. Drums are divided into two categories: sacred drums and secular drums. Sacred drums are endowed with the connotation and significance of traditional culture. According to local tradition, neither wooden drums nor their shelters can be relocated, even if the villages have moved away. Every Wa village has a wooden drum, which is used not only to convey information, but also to organize religious and entertainment activities. The drum is common property of the village, and relates to the production and life of all villagers. Wing Ding primitive tribe has a pair of traditional wooden drums: a male drum and a female drum. Shape of the female drum is similar to genital, embodies Wa people's worship of reproduction. The worship of reproduction is the worship of another productive force: the reproductive ability. The particular cultural significance of wooden drums reflects the relationship between survival and reproduction of Wa people and the natural environment, which also makes the drum culture become an important source of environmental customary law.

\section{The Religion and Taboo Origin of Environmental Customary Law}

Religious beliefs and taboos exist in social groups as thoughts, ideas and consciousness. The religion of Wa nationality is relatively primitive worship of nature. From the existing information, Wa People's religious ideas and thoughts are full of awe and love towards nature. The worship comes from people's dependence on the natural environment. Human beings must protect the nature, since they cannot survive without the natural environment. The protection of nature promotes the harmonious development of man and nature. Through the way of religion and taboo, Wa people have fixed the idea that man and nature should live in harmony.

First, the religious belief of Wa People. Wa people believe that all things have souls; everything happens because of ghosts and gods. In ancient society, people living in the mountains understand natural and social phenomena which cannot be explained as the control of ghosts and gods. In their opinion, 'Mu Yi Ji" , or 'Mo Wei'in some areas, is the greatest god. He is the creator, and the world's highest ruler. For Wa people, 'Mu Yi Ji'can be the air, soil, landscape, or any form of substance. He is omnipotence. In order to worship 'Mu Yi Ji” , activities like dragging wooden drums and cutting oxtails should be held. Another god of Wa people is 'A Yi E" , who is a male family god. People need to worship 'A Yi E'in every important moment of life, such as marriage and funeral of society members. In addition, Wa people believe that gods exist in everything. 'There are gods of trees, rocks, ants, red deer, bears, tigers, elks, monkeys, horses, frogs, chicken, birds, mules, mice, parrots, owls, 
snakes, throstle, cuckoos...'[4] Wa people regard all kinds of animals and plants as gods, which reflects their natural worship, and their concept of the harmonious coexistence of human and nature.

Second, the original taboo. Taboo is 'a kind of prohibitive norm, which limits people's behaviors and choices, and be established through retribution punishments from natural forces, secular authorities and supernatural phenomena.'There are many taboos in traditional Wa culture of [5], which involves all aspects of production and life. According to relevant documents, the author divides these taboos into religious taboos and secular taboos.

Religious taboos are formed in the practice of religious activities, and reflect the attitudes and views of Wa people towards religion. Wa people believe that all things have souls; all of people's birth, old-age, illness and death are controlled by the soul. 'In the room, things cannot be placed in the altar arbitrarily; ghosts live in the place around posts, things cannot be placed there directly...... In planting season, you cannot sow until you worship the family god and the village god, otherwise seedlings cannot grow up well...... In the harvest season, we need to hold a harvest ceremony first; otherwise we cannot use the new rice" . These primitive religious taboos exist in the behaviors of Wa people. Except for religious taboos, all taboos belong to secular taboos. Secular taboos can be found in people's daily life, as well as their important life moments like birth, old age, sickness and death. 'If a woman gives birth to a baby, outsiders are not allowed to enter the house that day, otherwise the baby cannot grow up; no meat can be eaten on that day, otherwise the baby cannot fat up......If somebody gets sick, a traversed bamboo pole must be put on the door of his house, implying that there's a patient in the house; outsiders cannot enter the house, or stay overnight...... No one is allowed to cut trees or hunt wild animals in the sacred mountain......'[6] Traditional Wa culture expresses the desire of harmonious coexistence between man and the environment. At the same time, the harmonious coexistence is realized through these taboos.

On one hand, the concept of harmony between man and nature is rooted in the traditional culture and people's mind; on the other hand, religion and taboo norms guarantee the harmony between Wa people and nature in practice. Religion and taboos are also important source of the environmental customary law.

\section{The Institutional Practice Origin of Environmental Customary Law}

Institution includes rules and procedures of a group, as well as customs and habits formed under certain historical conditions. It is a standard system; social members create the institution for their own survival and development purposes. The institution is the embodiment of group members' views and opinions on the environment.

The first institution is Mo Ba system. Mo Ba means folk wizards in Wa language. They are 'familiar with the history and current situation of Wa people; they can clearly state human history from Si Gang Li until now; they know most habits and ethics; they are entitled to host various religious ceremonies; they know how to divine, call back the spirit of the dead, and communicate with gods.'Mo Ba lives in every Wa villages. [7] The main functions of Mo Ba include the following. First, Mo Ba needs to host important ritual activities, include making fire, sacrificing gods, building new houses and so on. Wa people believe that a project cannot be carried out smoothly without a ceremony hosted by Mo Ba, since gods do not bless the project. Second, Mo Ba needs to implement exorcism and witchcraft, and cure disease. Wa people hold that illness is caused by evil spirits. After Mo Ba expel the evil spirit, and help the patient to regain his soul, the patient will recover. Third, Mo Ba needs to interpret laws and settle disputes. They need to help villages to find their lost belongings, settle internal disputes, and mediate with other villages. Mo $\mathrm{Ba}$ is not only the media between man and nature, but also the traditional authority of Wa village. In addition, Mo Ba is the inheritor and promoter of Wa culture and spirit.

The second institution is A Wa Li. A Wa Li means daily behavior standards handed down from generation to generation in oral form. For Wa people, A Wa Li contains common sense, perceptions and behavior standards. It is the source of their traditional social orders. These established behavior 
norms stabilize the order of Wa village; people who violate them will be punished. Principles stipulated in A Wa Li include social norms and personal norms.

First, A Wa Li makes provisions of social order. According to the traditional Wa culture, people with high authority cannot be autocratic. Their power must be used according to moral rules. When anything crops, whey need to convene a village meeting to negotiate. When a dispute occurs, villagers are not allowed to take presumptuous actions. They need to negotiate with chiefs, or discuss the problem in village meetings. Second, A Wa Li stipulate personal norms. 'Kids, when eating, the head of chicken must be offered to male elders. If you visit other people's house, do not sit on hosts' bed. After growing up, you need to choose a good girl and get married. You can choose your aunts' daughters, but keep away from girls who share your surname. People with the same surname came from one single family hundreds of years ago, so you can not marry these girls. Otherwise you will lose the face of your whole family, and bring famine to the village. If people who share your surname have difficulties, you should help them as if they were your family members. If you encounter difficulties, you can also ask them for help, too. To work on their own, you need to earn food to eat and money to spend by yourself. If you get in trouble and your family cannot help you, you can borrow or beg for food. But you can never steal, steal things will be punished by the whole family...'[8] From these regulations, it can be seen that A Wa Li relates to every aspect of social and personal life, including social intercourse and marriage. These personal conduct standards reflect Wa peoples' concepts of justice and equality. Thus, A Wa Li is also one of the sources of the environmental customary law.

\section{References}

[1] Compile Group of Yunnan Province, The Investigation of Wa People's Social History, Yunnan People's Publishing House, Kunming, 1987.

[2] Y.P. Zuo, The Return of Wooden Drum: Research on Characteristics and Contemporary Values of Wa Culture, Yunnan University Press, Kunming, 2008.

[3] J.Q. Chen, L. Guo, Cultural Originality of Wa People's Primitive Law in Ximeng Wazu Autonomous County, J. Northern Legal Science. 4 (2008) 99,103.

[4] Editorial Committee of Yunnan Province. Investigation of Ethnic History of Wa People (Two), Yunnan People's Publishing House, Kunming, 1983.

[5] X.H. Zhang, Laws and Cultures in Multiracial Societies, Law Press • China, Beijing, 2011.

[6] F.R. Zhao, Wa Culture in China, The Ethic Publishing House, Beijing, 2005.

[7] Y.P. Zuo, The Return of Wooden Drum: Research on Characteristics and Contemporary Values of Wa Culture, Yunnan University Press, Kunming, 2008.

[8] J. Liu, L. Liang, et. al., Investigation of Wa People's Traditional Culture in Ximeng Wazu Autonomous County, The Nationalities Publishing House of Yunnan, Kunming, 2008. 